\title{
A Study of a Rudimentary Potable Water System in a Rural Community
}

\author{
Josue Ake, Karen Waight, Joselyn Romero, Thippi Thiagarajan* \\ Faculty of Science and Technology, University of Belize, Belmopan, Belize \\ Email: ${ }^{*}$ tthiagarajan@ub.edu.bz
}

Received 27 February 2015; accepted 27 March 2015; published 30 March 2015

Copyright (C) 2015 by authors and Scientific Research Publishing Inc.

This work is licensed under the Creative Commons Attribution International License (CC BY). http://creativecommons.org/licenses/by/4.0/

(c) (i) Open Access

\section{Abstract}

A comprehensive study was conducted to evaluate a rural community's efforts to solve its potable water problem. Residents of St. Margaret village has built a rudimentary water storage facility through their community efforts and run a network of water supply to the households of the village. The study analyzed the water quality of the reservoir for physical, chemical and microbiological parameters by using standard water quality measurements and compared it between the wet and the dry seasons. The results indicate that the temperature and the $\mathrm{pH}$ were highest in the month of April. The phosphate level was high during the month of November whereas the dissolved oxygen level was lowest during November. The presence of fecal coliforms and other pathogenic microbes such as Salmonella and Shigella suggested that the water bodies are not safe for human consumption. The survey of the households in the village also revealed that health ailments associated with gastrointestinal tract are common among the people using the water for drinking purpose. The community's effort in finding solution to their potable water problem has been demonstrated in the design and execution of the rudimentary reservoir in the St. Margaret village. Although majority of the inhabitants of the village have only primary-level education, they were able to carry out a major engineering project.

\section{Keywords}

Rudimentary Reservoir, Potable Water Quality, Rural Community

\section{Introduction}

The earliest recorded attempt to generate pure water dates back to 2000B.C. Early Sanskrit writings outlined methods for purifying water. These methods ranged from boiling or placing hot metal instruments in water to filtering the water through crude sand or charcoal filters. These writings suggested that the major motive in pu-

${ }^{*}$ Corresponding author.

How to cite this paper: Ake, J., Waight, K., Romero, J. and Thiagarajan, T. (2015) A Study of a Rudimentary Potable Water System in a Rural Community. Journal of Water Resource and Protection, 7, 449-455. 
rifying water was to improve the taste of drinking water. It was assumed that good tasting water was also clean. The Greeks and Romans designed amazing aqueducts to route water pathways and provide the first municipal water systems [1].

Waterborne diseases continue to be a major health problem in developing countries with estimated annual cases of over 2 billion [2]. Access to safe drinking water is an important health and development issue at national, regional and local levels. The availability of good-quality potable water is critical for preventing diseases and improving quality of life for rural populations of the developing countries [3]. Water from creeks and rivers contains various impurities due to weathering of rocks, leaching of soils, aerosol particles from the atmosphere and from several human activities, including mining, and the use of chemicals [4]. Drinking water pollution is a major issue the world facing today that causes waterborne diseases which lead to the death of hundreds millions of people [5].

Belize is a small country with a population of approximately 341,000, of which more or less half live in urban areas and half in rural areas [6]. The majority of the population is below thirty years old and is employed in agriculture, tourism, and other service sector. Belize has 18 major watersheds and these watersheds play a critical role in keeping the overall pristine nature of tropical ecosystem of Belize [7]. Most of the rural populations in the country depend upon these watersheds for their livelihood. St. Margaret village is a small rural community with about 250 households located in the Cayo District, and has approximately 1500 inhabitants. People from St. Margaret are mostly immigrants from neighboring countries who migrated to Belize during the 1980s and 1990s. Majority of them are peasants who either do Milpa farming or work as agriculture laborers. Most of the people from the village used to get their drinking water from two main water bodies namely the Dry Creek and the Santa Martha River, one on each side of the village.

Five years ago, the village community had come together and built a rudimentary water storage facility on a stream that originates from the nearby mountains and passes through the village. The households of the village are connected to this water storage facility through the pipe lines and this serves as their main source of potable water for most of the year. This water has no treatment at all. The objective of the current research is to investigate the water quality of this rudimentary storage facility that is being used by the households of St. Margaret village and compare the water quality between the wet season and the dry season.

\section{Materials and Methods}

\subsection{Study Period}

The study design consisted of an intensive water sampling from the rudimentary community reservoir on a monthly basis for a period of 3 months during wet season (October-December) and 3 months during dry season (February to April) of 2014. The total rainfall for the wet season for the dry months (February to March) for the study area is between 150 to $200 \mathrm{~mm}$ and the total rainfall for the wet season (October to December) is about $800 \mathrm{~mm}[8]$.

\subsection{Site Description}

The rudimentary reservoir was built across a small stream which is a tributary to the Santa Martha River. The geographical coordinates of the reservoir is $17.1^{\circ} \mathrm{N}$ and $88.6^{\circ} \mathrm{W}$ at an elevation of 138 meters above sea level. This reservoir has a dimension of 3 meters in height, 5 meters in width and 20 meters in length with a storage capacity of 25 thousand liters of water. Water level fluctuates depending on the water flowing in the creek which is directly influenced by rainfall (Figure 1 \& Figure 2).

\subsection{Onsite Water Quality Testing}

During each round of sample collection the physical and chemical parameters were measured by using the DR/ 850 colorimeter and YSI 599 Replaceable Module kit respectively. The parameters studied were: Temperature $\left({ }^{\circ} \mathrm{C}\right)$, Dissolved Oxygen $(\mathrm{mg} / \mathrm{L}), \mathrm{pH}$, conductivity (ms/cm), Turbidity (FTU), Nitrate (mg/L), Phosphate (mg/L) and Total Chlorine (mg/L).

\subsection{Testing for Bacterial Indicator Organisms}

Water samples were collected in pre-sterilized Wheaton sample bottles in morning hours and samples were 


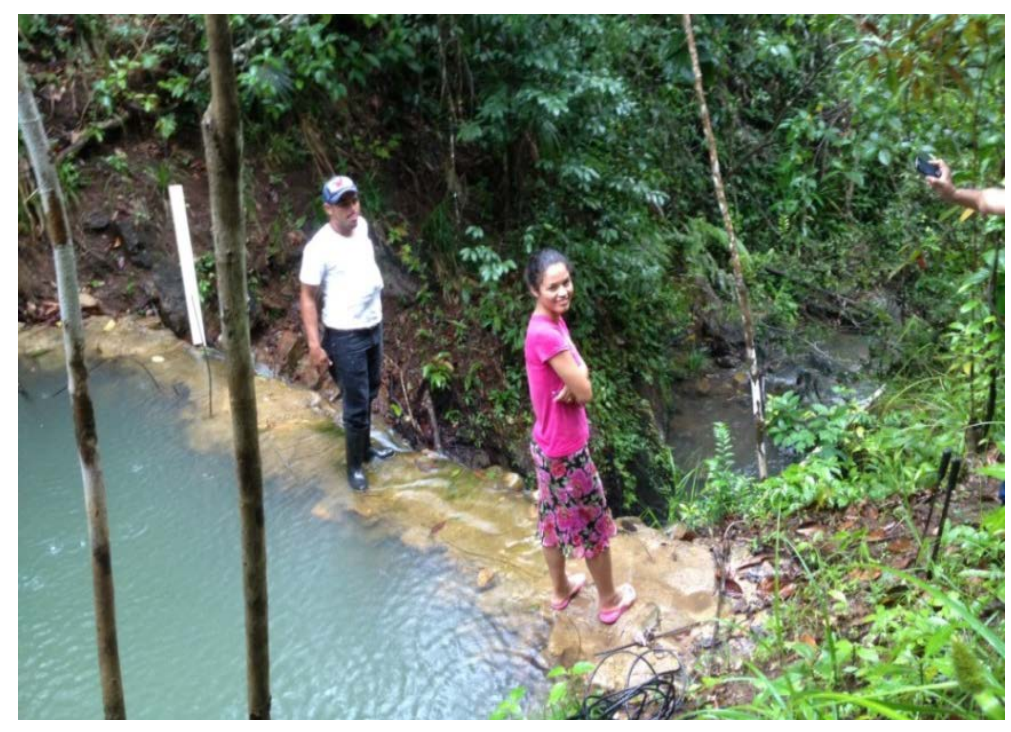

Figure 1. The rudimentary reservoir during wet season.

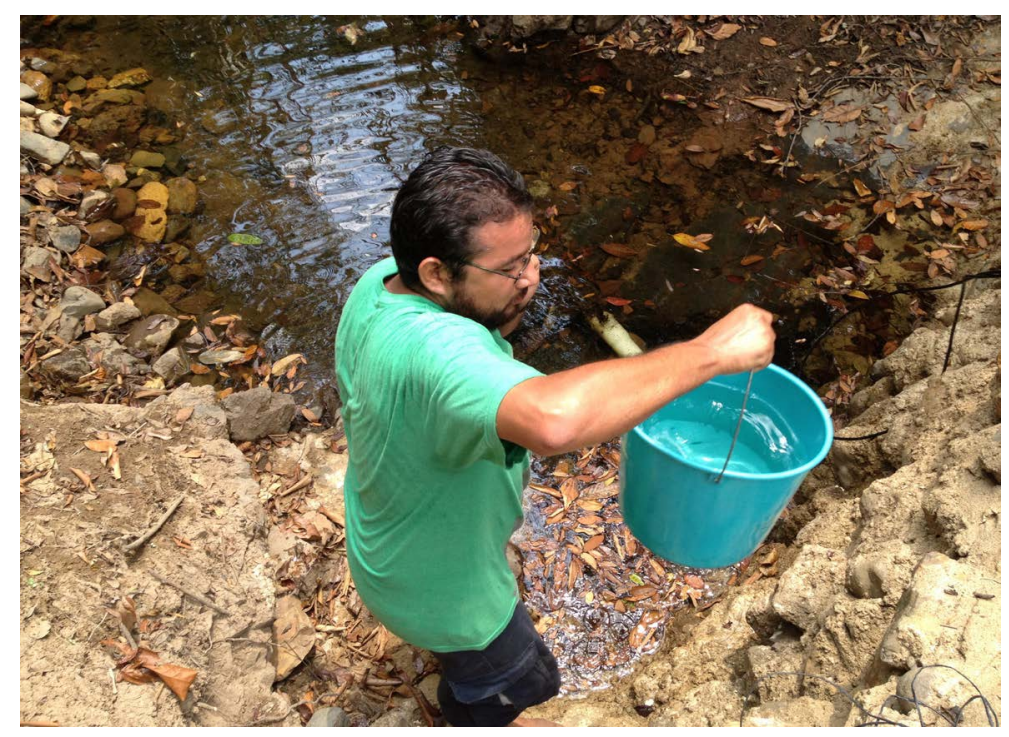

Figure 2. The rudimentary reservoir during dry season.

transported in cool boxes to the laboratory for further microbial analysis. Water samples were tested for presence of fecal coliforms by using serial dilution method on appropriate selective media agar plates. The presence of pathogenic indicator organisms such as Salmonella and Shigella were also tested by using appropriate selective media during the wet season. All protocols were done as per microbiological standards under aseptic conditions. Samples were diluted as necessary and replicate plates were incubated under required temperature and the colony forming units (CFUs) were enumerated. All chemicals and reagents were obtained from reputed suppliers and were of analytical grade.

\subsection{Survey}

A survey instrument was developed and administered among the households of the St. Margaret village. The purpose of the survey was to collect some baseline data on the health issues associated with the consumption of the water from the reservoir by the residents of the village. 50 households were randomly selected and interviews were conducted and questionnaires were filled out by the research team. 


\section{Results}

The reservoir was a community effort to find solution to their daily water problems. Since there was no treated potable water supply available in the village, and fetching water from nearby creek or river is laborious and time consuming, the community had decided to built a structure on the creek 100 meters high above the village at a remote location about 500 meters south of the village on the mountains. The structure was built with lime stone rocks that are available locally and the walls were raised with cement mortar supported by some steel reinforcement. The pipe lines were installed with some level engineering with proper large outlets for drainage to remove excess silt and debris from time to time. This ingenuity is commendable given the education level of the villagers where most of them are uneducated or with only primary school education. The water pipes that run from the reservoir to the village are 2 inch PVC type which runs close to 500 meters to reach the village. The water is distributed throughout the village with $3 / 4$ or $1 / 2$ inch facets in to the yards of most of the households. This rudimentary system is fully planned, funded and developed by the villagers to solve their potable water problem. The village chairman collects a moderate voluntary fee of BZ 3\$ towards the maintenance cost of the facility. The water is available for most of the year except during the months of April and May when the creek is dry.

The results for physical, chemical and microbiological parameters were averaged and presented in tables and graphs as necessary. Table 1 summarizes the data for the physical parameters. Belize being a sub-tropical country, the temperature remained between 22 and 27 degrees Celsius. The highest was in April when the temperature recorded $26.66^{\circ} \mathrm{C}$. Similarly the $\mathrm{pH}$ was also highest during the month of April with a $\mathrm{pH}$ of 9.72 which suggests the water is alkaline. It should be noted that the creek originates from and runs through the calcium rich Maya Mountain Range. When the water level decreased during the dry month of April, the pH increased. The turbidity was highest during the month of October and was lowest during dry season. Since October is one of wettest months, the creek gets flooded during this month and hence the turbidity was high. The conductivity remained more or less constant and did not show major difference between dry season and wet season.

Table 2 summarizes the results for the chemical and microbial data. The concentration of chlorine and nitrates were at acceptable level both during wet and dry season. The dissolved Oxygen level was highest during the month of February and lowest during the month of November. The fecal coliform level was high during the month of November. The phosphate level was high during the month of November. It should be noted that phosphate level can cause heterotrophic organisms to proliferate which causes depletion of dissolved oxygen in

Table 1. Results for the physical parameters.

\begin{tabular}{ccccc}
\hline Parameters & Temperature $\left({ }^{\circ} \mathbf{C}\right)$ & $\mathbf{p H}$ & Conductivity (ms/cm) & Turbidity (FTU) \\
\hline February & 22.54 & 8.17 & 0.024 & 1 \\
March & 22.51 & 4.45 & 0.031 & 1 \\
April & 26.66 & 9.72 & 0.031 & 0.025 \\
October & 24.94 & 4.46 & 0.029 & 3 \\
November & 23.06 & 4.84 & 0.026 & 1 \\
December & 23.55 & 4.65 & & 2 \\
\hline
\end{tabular}

Table 2. Results for the chemical and microbial parameters.

\begin{tabular}{|c|c|c|c|c|c|}
\hline Parameters & $\begin{array}{c}\text { Chloride } \\
\text { (mg/L) }\end{array}$ & $\begin{array}{l}\text { Nitrates } \\
(\mathrm{mg} / \mathrm{L})\end{array}$ & $\begin{array}{l}\text { Phosphates } \\
\text { (mg/L) }\end{array}$ & $\begin{array}{c}\text { Dissolved Oxygen } \\
\text { (mg/L) }\end{array}$ & $\begin{array}{c}\text { Fecal Coliforms } \\
\text { (CFU/mL) }\end{array}$ \\
\hline February & 0.03 & 0.03 & 0.71 & 4.55 & 55 \\
\hline March & 0.01 & 0.03 & 0.65 & 6.34 & 60 \\
\hline April & 0.02 & 0.03 & 0.73 & 4.5 & 64 \\
\hline October & 0.05 & 0.02 & 0.13 & 5.36 & 34 \\
\hline November & 0.02 & 0.01 & 2.75 & 1.26 & 86 \\
\hline December & 0.02 & 0.02 & 0.20 & 2.46 & 35 \\
\hline
\end{tabular}


the water bodies [9] [10]. Table 2 also shows the results for the fecal coliforms present in water for the study period. It is evident that there is fecal contamination of water during the wet and dry seasons. Since human and animal activities are seen in the watershed area, fecal matter can leach in to the water bodies and hence there is a presence of microbial population.

Figure 3 shows the results for the data on the presence of Shigella and Salmonella. Presence of these indicator organisms suggests fecal contamination of the water in the reservoir. Rainfall has a direct impact on the nutrient leaching and fecal contamination of water bodies as run-off water carries human and animal waste in to the nearby water bodies [11] [12].

The survey results gave some interesting information about the community of St. Margaret village. $72 \%$ of the persons surveyed have primary level education, $14 \%$ had no formal education and another $14 \%$ had high school level education. $74 \%$ housholds used out house (open pit) latrine and $26 \%$ have toilets with septic tanks. $46 \%$ of the people believed their water is contaminated and 54\% said their water is not contaminated. Figure 4 shows the primary purposes for which the people used the water from the reservoir. Close to $50 \%$ of the households used the water for drinking purpose. Over $70 \%$ of the households used it for other domestic purposes.

Figure 5 summarizes the various health disorders experienced by the villagers during the year 2014. It is evident that gastrointestinal disorders were the most common ones (diarrhoea, vomiting and abdominal pain) with a total of $44 \%$ and skin disorders were the least with only $2 \%$. Hepatitis was experienced by $10 \%$ people and $44 \%$ did not experience any ailments.

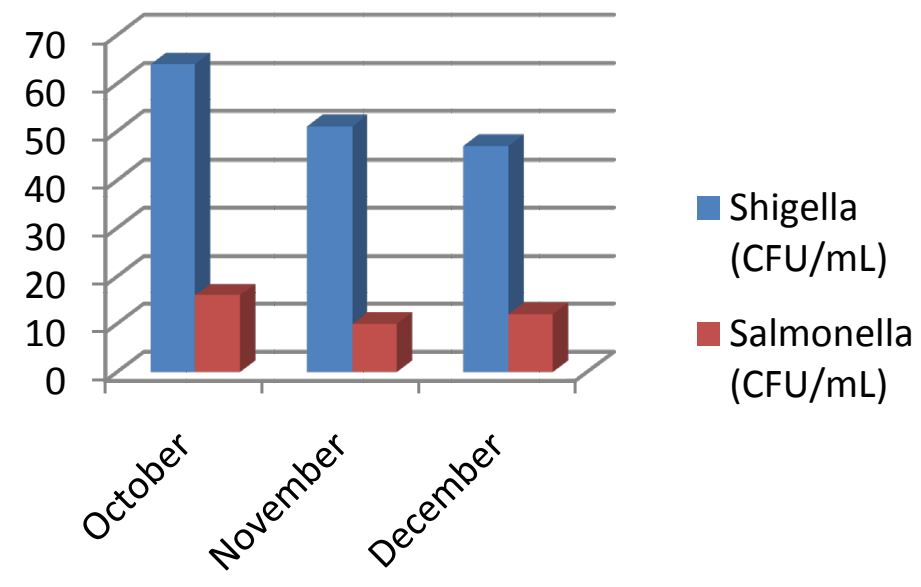

Figure 3. Shigella and Salmonella concentration during wet season.

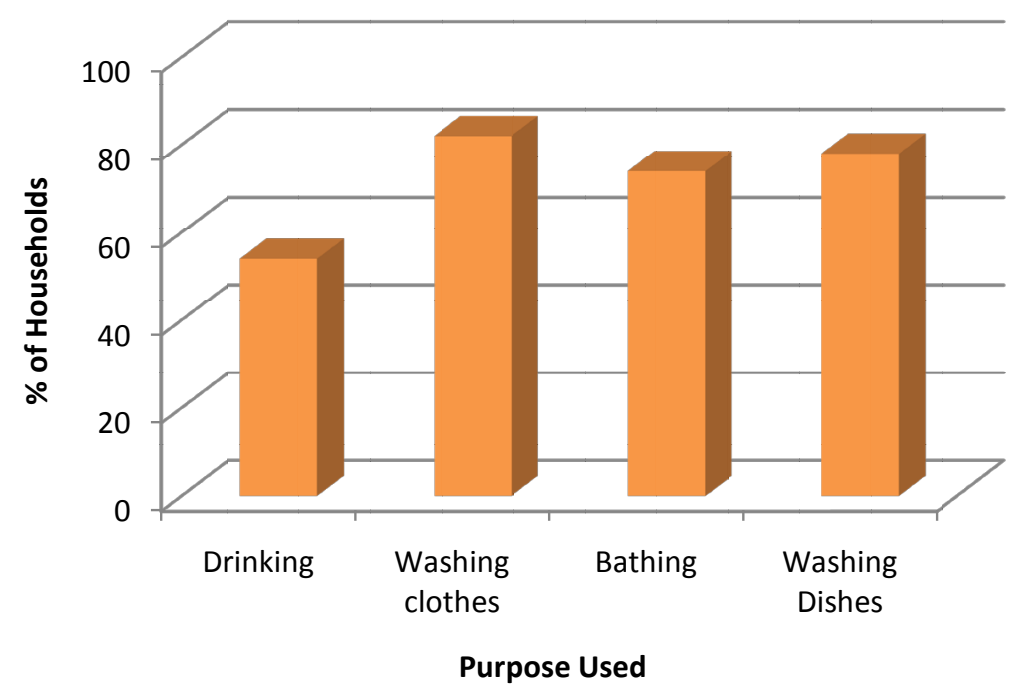

Figure 4. Household use of potable water from the community reservoir. 


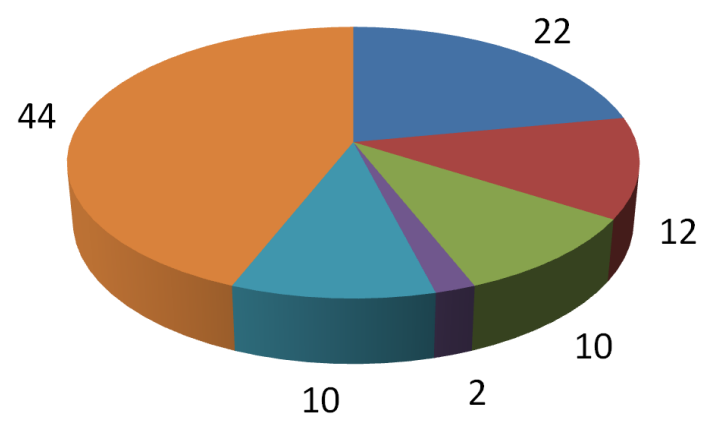

Diarrhea

- Vomitting

Abdominal Pains

Skin Rashes

Hepatitis

None

Figure 5. Health ailments experienced by the households.

\section{Discussion}

Quality potable water is an important basic requirement for a healthy human life [13]. Belize has close to 55\% of the population living in rural areas [6]. Although urban areas and large village communities get government attention in getting potable water, rural areas with lesser population are not getting their due share. Rural population also deserves quality potable water. Villagers with limited knowledge on water quality believe that running water in creeks and streams in the forest area are pristine and free of contamination. However there is need to create awareness among the rural population. Many studies relate fecal contamination of water bodies to enteric diseases in human populations [14] [15]. The survey of the residents of the St. Margaret village indicated that many of them suffer from diarrhoea and other gastrointestinal disorders associated with consumption of water from the reservoir. Since the results indicated presence of microbial contamination in the water throughout the study period, it can be inferred that fecal contamination of reservoir leads to health disorders in the population [16]. Since farming activities are found around the watershed area of St. Margaret village, there is high chance of animal fecal contamination reaching the creeks during rainy season. Water quality monitoring is necessary for prevention of waterborne diseases and organisms such as Shigella and Salmonella are important indicator microorganisms in that exercise [10].

\section{Conclusion and Recommendations}

People living in the rural areas do not have access to treated potable water. A community effort such as the one taken by residents of St. Margaret village is commendable. However, proper education on water quality monitoring is important for the community to manage their water resource. The main source of water for most of the rural population in Belize is mainly rivers and creeks that run adjacently to their communities. These water bodies are used for recreational as well as domestic purpose including drinking water. It is a cultural practice in many rural villages in Belize where they believe the creeks and streams are uncontaminated. The study highlights the need for awareness of water quality for the people living in the villages of Belize. Government also ought to provide healthy drinking water for the public to avoid serious health risk associated with the consumption of contaminated water. There is a critical need for educating rural households on the importance of drinking water quality and health risk associated with consumption of contaminated water.

\section{References}

[1] Juuti, P.S., Katko, T.S. and Vuorinen, H.S. (2006) Environmental History of Water-Global View of Community Water Supply Sanitation. IWA Publishing, London.

[2] WHO (2002) The World Health Report 2002. World Health Organisation, Geneva.

[3] Oluduro, A.O. and Adewoye, B.I. (2007) Efficiency of Moringa oleifera Seed Extract on the Microflora of Surface and Ground Water. Journal of Plant Science, 6, 453-438.

[4] Asaolu, S.S., Ipinmoroti, K.O., Adeyinowo, C.E. and Olaofe, O. (1997) Interrelationship of Heavy Metals Concentration in Water, Sediment as Fish Samples from Ondo State Castal Area, Nigeria. African Journal of Science, 1, 55-61.

[5] Adefemi, S.O. and Awokunmi, E.E. (2010) Determination of Physico-Chemical Parameters and Heavy Metals in Water Samples from Itaogbolu Area of Ondo-State, Nigeria. African Journal of Environmental Science and Technology, 4, $145-148$. 
[6] Statistical Institute of Belize (2010) Population and Housing Censes, Report 2010.

[7] Boles, Ed. (1999) The Sibun River Watershed Atlas. Sibun Watershed Association and The Government Printer, Belmopan, Belize.

[8] Belize Meteorological Service 2014. http://www.hydromet.gov.bz/monthly-rainfall-summary

[9] Kinzelman, J., Ng, C., Jackson, E., Gradus, S. and Bagley, R. (2003) Enterococci as Indicators of Lake Michigan Recreational Water Quality; Comparison of Two Methodologies and Impact on Public Health Regulatory Events. Applied Environmental Microbiology, 69, 92-96. http://dx.doi.org/10.1128/AEM.69.1.92-96.2003

[10] Mitch, A.A., Gasner, K.C. and Mitch, W.A. (2010) Fecal Coliform Accumulation within a River Subject to Seasonally Disinfected Wastewater Discharges. Water Research, 44, 4776-4782. http://dx.doi.org/10.1016/j.watres.2010.05.060

[11] Hill, D.D., Owens, W.E. and Tchounwou, P.B. (2006) The Impact of Rainfall on Fecal Coliform Bacteria in Bayou, Dorcheat (North Louisiana). International Journal of Environmental Research and Public Health, 3, 114-117. http://dx.doi.org/10.3390/ijerph2006030013

[12] Obire, M.A. and Puthetti, R.R. (2008) The Impact of Human Activities on Drinking Water Quality. Journal of Basic and Applied Biology, 2, 52-58.

[13] World Health Organization (2011) Guidelines for Drinking Water Quality. 4th Edition, WHO, Genève.

[14] Bain, R., Cronk, R., Wright, J., Yang, H. and Slaymaker, T. (2014) Fecal Contamination of Drinking-Water in Lowand Middle-Income Countries: A Systematic Review and Meta-Analysis. PLOS Medicine, 11, e1001644. http://dx.doi.org/10.1371/journal.pmed.1001644

[15] Gwimbi, P. (2011) The Microbial Quality of Drinking Water in Manonyane Community: Maseru District (Lesotho). African Health Science, 3, 474-480.

[16] Wade, T.J., Calderon, R.L., Brenner, K.P., Sams, E., Beach, M., Haugland, R., Wymer, L. and Dufour, A.P. (2008) High Sensitivity of Children to Swimming-Associated Gastrointestinal Illness Results Using a Rapid Assay of Recreational Water Quality. Epidemiology, 19, 375-383. http://dx.doi.org/10.1097/EDE.0b013e318169cc87 